\title{
Tiga Alasan Kuat Diperlukannya Penguatan Fungsi dan Kewenangan Badan POM
}

\author{
Decky Ferdiansyah \\ Badan Perenc anaan Pembangunan Daerah (Bappeda) Provinsi Lampung, Indonesia \\ Terbit online : 22 September 2016
}

\section{Abstrak :}

Dunia kefarmasian akhir-akhir ini kembali digegerkan dengan ditemukannya pabrik obat palsu oleh pihak Badan Reserse dan Kriminal Markas Besar Kepolisian Republik Indonesia (Bareskrim Mabes Polin) dan Badan Pengawas Obat dan Makanan (Badan POM). Banyak kalangan masyarakat yang masih belum memaham mengapa lembaga Kementerian Kesehatan dan Badan POM yang fungsinya bisa digabung. Ada tiga alasan perlunya memperkuat fungsi dan kewenangan Badan POM. Pertama, status kelembagaan. Alasan kedua adalah kewenangan penegakan hukum dan ketiga adalah dari sisi penganggaran. Jadi ketika pertanyaan tentang perlukah kewenangan Badan POM diperkuat? Maka kita tidak akan ragu lagi untuk menjawabnya dengan mengatakan sangatperlu dan mendesak.

Keyword : obatpalsu, Badan POM,

\section{Pendahuluan}

Dunia kefarmasian akhir-akhir ini kembali digegerkan dengan ditemukannya pabrik obat palsu oleh pihak Badan Reserse dan Kriminal Markas Besar Kepolisian Republik Indonesia (Bareskrim Mabes Polri) dan Badan Pengawas Obat dan Makanan (Badan POM).

\section{Penggerebekan obat palsu dan pelantikan Kepala Badan POM baru}

Penggerebekan itu dilakukan pada tanggal 9 September 2016 di kompleks pergudangan kawasan Balaraja - Tangerang. Sebelumnya, pada 23 November 2015 Mabes Polri dan Badan POM juga menyita puluhan ribu butir obat-obatan yang mengandung boraks di kompleks tersebut.

Masih di tempat yang sama, pada 21 Juni 2016 juga ditemukan 223 jenis obat dan jamu yang tidak memiliki izin edar Badan POM. Sehingga dalam kurun waktu yang tidak terlalu lama, terjadi tiga kali pelanggaran hukum dibidang obat dan makanan di tempat yang sama. Namun sampai saat ini pihak Badan POM belum bisa memastikan apakah ketiga kasus tersebut saling terkait dan melibatkan pelaku dan jaringan yang sama.

Pada tanggal 20 Juli 2016 bertempat di Istana Negara, Presiden Joko Widodo melantik Dr. Ir. Penny Kusumastuti Lukito, MCP sebagai Kepala Badan POM RI, bersamaan dengan pelantikan Komjen (Pol) Suhardi Alius sebagai Kepala Badan Nasional Penanggulangan Terorisme (BNPT). Ini sebuah tradisi baru. Sebelum-sebelumnya, Kepala Badan POM selalu dilantik oleh Menteri Kesehatan. Hal ini menegaskan bahwa Badan POM sebagai Lembaga Pemerintah Non Kementerian (LPNK) yang berada di bawah koordinasi Kementerian Kesehatan. 
Adakah benang merah antara pengungkapan kasus pelanggaran hukum dibidang obat dan makanan di atas dengan pelantikan Kepala Badan POM di istana? Mungkinkah ini menjadi sinyal akan adanya penguatan kelembagaan Badan POM oleh pemerintah?

\section{Menelaah regulasi yang mengatur Kementrian Kesehatan dan Badan POM}

Ada baiknya kita telaah bersama regulasi yang mengatur tugas dan fungsi lembaga Kementerian Kesehatan dan Badan POM. Banyak kalangan masyarakat yang masih belum memahami mengapa ada dua lembaga yang fungsinya bisa digabung ini. Bukankah sebaiknya Badan POM dilebur saja ke dalam struktur Kementerian Kesehatan? Toh ini sejalan dengan semangat efisiensi dan perampingan lembaga negara yang selalu diwacanakan oleh Kementerian Negara Pendayagunaan Aparatur Negara dan Reformasi Birokrasi (Kemenpan RB).

Undang-Undang No. 39 Tahun 2008 tentang Kementerian Negara mengatur bahwa kementerian berada di bawah dan bertanggung jawab kepada Presiden. Sehingga jelas bahwa dalam struktur pemerintahan, kementerian negara merupakan struktur pemerintahan tertinggi di bawah Presiden. Presiden sebagai pemegang kekuasaan tertinggi dibantu oleh para menterinya dalam menjalankan roda pemerintahan. Menteri merupakan anggota kabinet.

UU Kementerian Negara juga mengatur bahwa unusan kesehatan sebagai salah satu urusan wajib pemerintah yang menuntut adanya struktur tersendiri di dalam pemerintahan. Urusan kesehatan inilah yang tugas dan fungsinya dilaksanakan oleh Kementerian Kesehatan. Terlebih lagi urusan kesehatan secara jelas disebutkan ruang lingkupnya di dalam Undang-Undang Dasar Negara Republik Indonesia Tahun 1945. Dalam Sistem Kesehatan Nasional, urusan kesehatan ini mencakup beberapa subsistem, diantaranya adalah subsistem sediaan farmasi, alat kesehatan dan makanan. Obat dan makanan masuk ke dalam subsistem ini. Tugas dan fungsi dibidang pengawasan obat dan makanan inilah yang menjadi kewenangan Badan POM.

\section{Sejarah terbentuknya Badan POM}

Pada mulanya, Badan POM berada di dalam struktur Departemen Kesehatan dengan nama Direktorat Jenderal Pengawasan Obat dan Makanan (Ditjen POM) setingkat eselon I. Pada masa Presiden Megawati Soekarnoputri, Ditjen POM "dlepas" dari Departemen Kesehatan dan menjadi Lembaga Pemerintah Non Departemen (LPND) dan nomenklaturnya diganti menjadi Badan POM. Badan POM dipimpin oleh seorang kepala setingkateselon I.

Lembaga ini dibentuk berdasarkan Keputusan Presiden No. 103 Tahun 2001 tentang Kedudukan, Tugas, Fungsi, Kewenangan, Susunan Organisasi, dan Tata Kerja Lembaga Pemerintah Non Departemen. LPND ini dibentuk untuk melaksanakan tugas pemerintahan tertentu dari Presiden. Sehingga kedudukannya berada di bawah dan bertanggung jawab langsung kepada Presiden. Kendatipun demikian, dalam melaksanakan tugasnya masingmasing LPND wajib berkoordinasi kepada menteri terkait. Khusus untuk Badan POM berkoordinasi kepada Menteri Kesehatan RI. Sehingga dapat dipahami bahwa Kepala Badan POM berada di bawah koordinasi Menteri Kesehatan sebagai penanggung jawab tertinggi urusan pemerintah di bidang kesehatan.

\section{Usulan Komisi IX DPR RI untuk merevisi regulasi}

Seiring dengan semakin banyaknya kasus pelanggaran hukum dibidang obat dan makanan, maka akhir-akhir ini mengemuka pendapat untuk memperkuat fungsi dan kewenangan Badan POM. Tidak kurang dari Ketua Komisi IX DPR RI Dede Yusuf yang meminta Presiden $\mathrm{RI}_{1}$ untuk merevisi Peraturan Presiden No. 103 Tahun 2001 yang mengatur tentang fungsi dan kewenangan Badan POM. 
Sebenarnya, pemerintah dan DPR RI telah sepakat untuk melakukan pembahasan Rancangan Undang-Undang (RUU) tentang Pengawasan Obat dan Makanan dimana di dalamnya tercantum penguatan kelembagaan Badan POM. Namun sebagaimana umumnya pembahasan sebuah RUU akan memakan waktu yang cukup lama. Terlebih lagi, RUU tentang Pengawasan Obat dan Makanan tersebut tidak masuk dalam Program Legislasi Nasional (Prolegnas) DPR RI Tahun 2016.

Maka jalan yang paling cepat untuk memperkuat fungsi dan kewenangan Badan POM adalah dengan merevisi Peraturan Presiden (Perpres) yang melahirkan lembaga Badan POM tersebut. Anggota Komisi IX DPR RI Adang Sudrajat menambahkan bahwa pembahasan penyusunan RUU tentang Pengawasan Obat dan Makanan baru akan mulai diagendakan di Tahun 2017 atau 2018.

Dalam RUU tersebut salah satunya akan dimasukkan tentang kewenangan penindakan hukum oleh Badan POM. Badan POM dinilai perlu memiliki landasan hukum berupa undang-undang untuk mendapatkan kewenangan atributif, agar kewenangan dalam menjalankan tugas tidak lagi bersifat delegatif.

\section{Tiga alasan diperlukannya penguatan fungsi dan kewenangan Badan POM Status kelembagaan}

Dari uraian di atas, maka kita memahami bahwa setidaknya ada tiga alasan perlunya memperkuat fungsi dan kewenangan Badan POM. Pertama, status kelembagaan. Wilayah kerja Badan POM addah pengawasan seluruh produk obat dan makanan yang beredar di seluruh Indonesia. Secara kelembagaan, Badan POM memiliki unit pelaksana teknis (UPT) berbentuk Balai/Balai Besar di setiap ibukota provinsi.

Badan POM tidak memiliki unit pelaksana teknis di setiap kabupaten/kota. Hal ini tentu membuat area yang harus diawasi oleh setiap Balai/Balai Besar POM menjadi sangat luas. Untuk beberapa provinsi yang memiliki kepulauan ataupun kondisi geografis yang masih terisolir maka akan cukup menyulitkan. Tidak adanya unit pelaksana teknis di setiap kabupaten/kota membuat Balai/Balai Besar POM di provinsi harus bisa memilah tingkat prioritas wilayah pengawasannya. Tentunya harus ada skala prioritas terhadap beberapa wilayah yang dinila rawan akan terjadinya pelanggaran hukum dibidang obat dan makanan.

\section{Kewenangan penegakan hukum}

Alasan kedua adalah kewenangan penegakan hukum. Kewenangan penegakan hukum berupa penindakan yang dilakukan Penyidik Pegawa Negeri Sipil (PPNS) di Badan POM hanya dari sisi menetapkan tersangka terhadap orang/korporasi yang diduga melakukan pelanggaran hukum. Jumlah PPNS yang dimiliki Badan POM-pun sampai saat ini sangat terbatas dibandingkan dengan jumlah kasus yang perlu ditindaklanjuti. Selain keterbatasan tersebut, PPNS di Badan POM dalam hal penyelidikan kasus pelanggaran hukum hanya bersifat administratif untuk menemukan fakta di lapangan.

Badan POM tidak memiliki kewenangan untuk melakukan penahanan terhadap tersangka yang sudah mereka tetapkan. Penahanan hanya bisa dilakukan melalui bantuan kepada pihak kepolisian. Dalam Rapat Bersama di Komisi IX DPR RI, Kepala Badan POM Penny K. Lukito menyebutkan bahwa PPNS Badan POM tidak memiliki kewenangan dalam penggeledahan, penangkapan dan penahanan tersangka. Hal ini cukup menyulitkan prosedur di lapangan dalam penindakan kasus pelanggaran hukum dibidang obat dan makanan. 
Dalam kesempatan yang sama, Kabareskrim Komjen (Pol) Ari Dono menjelaskan bahwa Penyidik PNS tidak memiliki kewenangan sebesar penyidik kepolisian. Dia mencontohkan dalam hal penangkapan dimana pelaku bisa saja melakukan perlawanan terhadap Penyidik PNS.

Pada Pertemuan Koordinasi Lintas Sektor Penegakan Hukum Tindak Pidana Obat dan Makanan 22 - 24 Agustus 2016 di Bogor, disepakati bahwa penguatan sinergi penegakan hukum Badan POM dengan lintas sektor terkait dalam kerangka Criminal Justice System (CJS). Kerangka ini diharapkan menjadi salah satu solusi dalam menyelesaikan beberapa kendala teknis dan yuridis dalam penanganan perkara pelanggaran hukum dibidang obat dan makanan.

Dalam beberapa kasus pelanggaran yang diduga terjadi di sarana kesehatan yang berizin, Badan POM masih berupa memberikan rekomendasi kepada Dinas Kesehatan setempat untuk menindaklanjuti kasus. Rekomendasi ini biasanya berupa pencabutan terhadap izin sarana kesehatan tersebut.

Kewenangan eksekusi di instansi lain ini akhimya menjadikan Badan POM kerap tidak "bertaji" ketika suatu kasus terjadi di wilayah administratif kabupaten/kota. Terlebih bila kasus yang terjadi melibatkan beberapa oknum yang dekat dengan kepala daerah setempat. Rekomendasipun menjadi tidak efektif dan tidak menimbulkan efek jera kepada para pelaku.

\section{Sisi penganggaran}

Alasan ketiga adalah dari sisi penganggaran. Anggaran yang tersedia setiap tahunnya dirasa masih kurang dibandingkan dengan tugas dan fungsi pengawasan obat dan makanan yang beredar di seluruh Indonesia. Anggaran yang memadai akan membuat Badan POM mampu memperkuat kelembagaannya sampai pada tingkat kabupaten/kota dan didukung oleh SDM dan sarana prasarana yang memadai. Visi Badan POM adalah obat dan makanan aman meningkatkan kesehatan masyarakat dan daya saing bangsa. Visi besar ini akan lebih mudah terwujud dengan dukungan anggaran yang memadai.

Jadi ketika pertanyaan tentang perlukah kewenangan Badan POM diperkuat? Maka kita tidak akan ragu lagi untuk menjawabnya dengan mengatakan sangat perlu dan mendesak. Mudahmudahan dapat segera direalisasikan.

\section{Daftar Pustaka :}

Republik Indonesia, 2008 Undang-Undang Kementerian Negara, Jakarta: Sekretariat Negara Republik Indonesia, 2009 Undang-Undang Kesehatan, Jakarta : SekretariatNegara Republik Indonesia, 2001 Peraturan Presiden tentang Kedudukan, Tugas, Fungsi, Kewenangan, Susunan Organisasi, dan Tata Kerja Lembaga Pemerintah Non Departemen, Jakarta:

SekretariatNegara 